
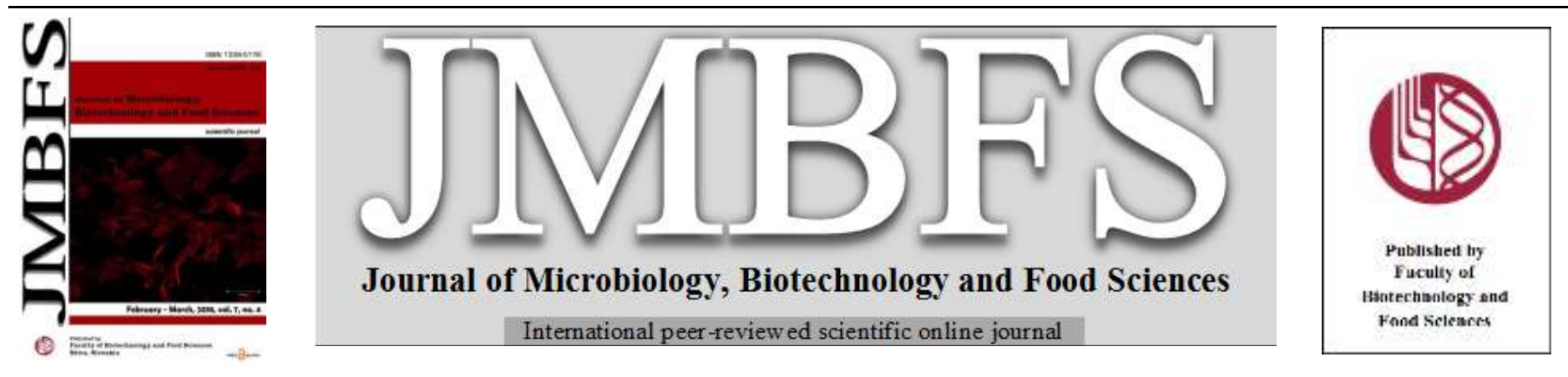

\title{
INDUCED TEMPORAL AND SPATIAL VARIATION IN HOST DEFENCE ENZYMES IN RESPONSE TO FUSARIUM WILT IN CHICKPEA
}

\author{
Jhuma Datta ${ }^{1,2}$ and Nand Lal ${ }^{1, *}$ \\ $\operatorname{Address}(e s):$ \\ ${ }^{1}$ Department of Life Sciences, C.S.J.M. University, Kanpur 208024. \\ ${ }^{2}$ Present Address: Department of Biochemistry, BCKV-Burdwan Campus, Burdwan-713101.
}

*Corresponding author: $\underline{\text { nl_pr@yahoo.co.in }}$

doi: $10.15414 / j m b f s .2018 .7 .4 .426-431$

\section{ARTICLE INFO}

Received 27. 10. 2017

Revised 21. 12. 2017

Accepted 2.1.2018

Published 1. 2. 2018

Regular article

orten 2 acctss

\section{ABSTRACT}

The present study evaluated the defense response of Chickpea wilt resistant and susceptible cultivars inoculated with pathogen Fusarium oxyporum f.sp. ciceri (Foc). Evaluation of pre-induced and pathogen-induced defense at 7 (S1), 15 (S2) and 30 (S3) days showed that the enzymatic activities differed not only within the root, stem and leaves but also between susceptible and resistant cultivars of chickpea and increased after inoculation with Foc. Peroxidase (PO) activity increased in all the tissues from S1 to S2 and declined thereafter. Conspicuous changes occurred at the rate of increase in activity of the enzyme between resistant and susceptible cultivars upon Foc inoculation over their corresponding control at the S2. Polyphenol oxidase (PPO) activity in resistant cultivars increased by $30 \%$ with over uninoculated control and induction was up to S3. The level of enzyme activity diminished from S2 to S3 and even fell below control levels in susceptible cultivars. Catalase (CAT) activity followed peroxidase trend however it was induced at S1 in Foc inoculated and at S2 in un-inoculated plants. Increase in CAT induction was significant in leaf tissues of infected plants and continued up to S3. Phenylalanine ammonia lyase (PAL) activity increased from S1 to S2 and thereafter it either slightly decreased or remained unchanged at S3. Foc inoculation elicited a sharp increase in PAL activity in the leaf and stem tissue of resistant cultivars. Foc inoculated induced $\beta$-1,3-glucanase and chitinase activity in the test cultivars. Maximum induction of chitinase was observed at S2 in roots of resistant cultivars whereas un-inoculated plants showed much less conspicuous changes. $\beta$-1,3-glucanase activity was high in stem tissues. Both control and challenged plants had higher levels of $\beta$-1,3-glucanase activity at S2 and S3, but the proportionate increase was much higher in resistant cultivars. The expression pattern of these defense enzymes reveals their use as established resistance markers and provides scope for manipulating their expression and development of wilt-resistant transgenic chickpea.

Keywords: Chickpea, Cicer arietinum, Fusarium oxyporum f.sp. ciceri, Pathogenesis, Defence enzymes

\section{INTRODUCTION}

Chickpea (Cicer arietinum L.) is a self-pollinated diploid $(2 \mathrm{n}=2 \mathrm{x}=16$ with genome size of $738 \mathrm{Mb}$ ) leguminous crop, cultivated mainly in semiarid environments of the world and ranks second in area and third in production among the pulses worldwide. Around $65 \%$ of the total global area and around $68 \%$ of total global production of chickpea falls in India. Although much progress has been made in developing chickpea lines with resistance to biotic constraints and tolerance to abiotic stresses, yield loss in these crops is very high due to the high incidence of diseases and insect pests. Chickpea wilt caused by Fusarium oxysporum Schl.Emend.Snyd and Hans f.sp. ciceri (Padwick) is widespread in several chickpea growing regions of the world, especially the Indian subcontinent, Ethiopia, Mexico, Spain and Tunisia (Joshi et al., 2001). The wilt pathogen is both soil and seed borne and difficult to eradicate as fungal chlamydospores survive in soil up to six years even in the absence of host plant (Haware et al., 1996). Fusarium wilt epidemics can be devastating to individual crops and cause up to $100 \%$ loss under favourable conditions.

Understanding of the molecular basis of pathogenesis and resistance mechanism is very important for developing effective strategy for management of wilt diseases. Plants activate a large array of defence mechanisms in response to pathogen attack and host-pathogen cross-talk. A crucial factor determining the success of these mechanisms is the speed of their activation which needs thorough understanding of how host plants recognize pathogen attack and contro expression of defence mechanisms. The hypersensitive response of plants is accompanied by the synthesis of number of host proteins thought to be involved in defence mechanisms. Defense-related enzymes constitute an important protective system for plants against pathogen invasion such as PAL is the primary enzyme in phenylpropanoid metabolism and plays an important role in the synthesis of several defense-related secondary compounds known as phytoalexins (Tahsili et al., 2014). Differential expression of PAL genes was investigated using northern blot analysis in chickpea seedlings challenged with Fusarium oxysporum f. sp. ciceri (Arfaoui et al., 2007). Broetto et al. (2005) reported strong induction of the PAL and increased de novo synthesis of PALmRNA in bean, Phaseolus vulgaris L. infected by Fusarium oxysporum $\mathrm{f}$. sp. phaseoli. Researches on elucidation of host defensive responses to pathogen invasion have determined catalase, superoxide dismutase (SOD), peroxidase (PO), polyphenol oxidase (PPO), phenylalanine ammonia-lyase (PAL) and "pathogenesis related" (PR) proteins viz. chitinase and $\beta$-1,3-glucanase as vital defense-related enzymes of plants, and extensively studied in the research of plant defense against phytopathogens (Swarupa et al., 2014, Dehgahi et al., 2015). Ramachandra et al. (2000) suggested use of $\beta$-1,3-glucanase as a biochemical marker for screening of downy mildew resistant cultivars in pearl millet (Pennisetum typhoides) on the basis of differential enzyme activity among resistant and susceptible cultivars. Similarly, Giri et al. (1998) observed the differential induction of chitinase activity in susceptible and resistant cultivars of chickpea and decrease in $\beta$-1,3-glucanase in the resistant cultivars in response to the pathogen infection. The observed decrease in $\beta$-1,3-glucanase in the resistant cultivars contributed to reduction in pathogen invasion as a result of the defence reaction. Expression of the few member enzymes of host defense system may be constitutive while others are induced upon the attack of pathogen like enzymes involved in phytoalexin biosynthesis or induction of antioxidant and its related enzymatic system.

Since information on pre-induced and induced biochemical mechanisms of resistance are pre-requisite for better understanding of the pathogens-host interaction and provide basis for better management of disease, the present investigations were carried as an attempt to analyse and correlate the biochemical basis of disease resistance, by measuring levels of peroxidise, catalase, PPO, 
PAL, $\beta$-1,3-glucanase and chitinase spatially and temporally in wilt resistant and wilt susceptible cultivars of chickpea.

\section{MATERIAL AND METHODS}

Plant material, pathogen inoculation and sample collection for biochemical analyses

Two each of wilt resistant (WR 315, ICC 4958) and wilt susceptible (JG 62, BG 256) cultivars of chickpea (Cicer arietinum L.) were used for the present study. The Fusarium oxysporum f. sp. ciceri (Foc) pathogens were isolated from fourthnode stem sections taken from wilted chickpea plants according to the procedure described by Tullu $\boldsymbol{e t}$ al. (1998) and were colonized on filter paper, dried in the transfer hood, and aseptically cut into small pieces. The colonized filter paper pieces were placed in potato-dextrose broth and incubated to produce liquid cultures of the pathogen. The liquid cultures were filtered through cheese cloth to remove mycelia. The spore suspension was pelleted by centrifugation. After discarding the supernatant, the conidia were washed with sterile water to adjus the spore suspension to $1 \times 10^{6}$ spores $\mathrm{ml}^{-1}$ with a haemocytometer. Single spore culture of fungus was obtained by serial dilution method. Isolated fungus was identified as $F$. oxysporum f. sp. ciceri and its pathogenicity test was conducted in pot experiments on chickpea cultivar, JG 62. Plastic pots of $30 \mathrm{~cm}$ diameter, surface-sterilized with $0.1 \%$ w/V mercuric chloride $\left(\mathrm{HgCl}_{2}\right)$, were filled with $2 \mathrm{~kg}$ sterilized soil (three subsequent sterilizations at $1.1 \mathrm{~kg} / \mathrm{cm}^{2}$ for $1 \mathrm{~h}$ for 3 days). Seven days before sowing, pots were inoculated with the 14-day-old culture of the pathogen multiplied on sand maize meal water medium $(90 \mathrm{~g}$ sand, $10 \mathrm{~g}$ maize meal and $20 \mathrm{ml}$ distilled, sterilized water) @ $50 \mathrm{~g} \mathrm{~kg}^{-1}$ soil. Ten seeds (surface-sterilized using $2 \%$ sodium hypochlorite for $3 \mathrm{~min}$, and rinsed in sterile water) of each cultivar were sown in each pot for disease scoring.

The root, shoot and leaf tissues were collected separately at 7 (S1), 15 (S2) and 30 (S3) days after sowing (DAS) and were frozen immediately in liquid nitrogen to store at $-20^{\circ} \mathrm{C}$. Biochemical basis of disease resistance was studied by changes (temporal and spatial accumulation and activity) in defence enzymes (peroxidase, polyphenol oxidase, phenylalanine ammonia lyase, chitinase, and $\beta-1,3$ glucanase) in Fusarium wilt resistant and susceptible genotypes.

\section{Extraction of antioxidant enzymes}

The tissue samples (500 mg fresh weight) were ground in $0.1 \mathrm{M}$ phosphate buffer (pH 7.0) in a pre-chilled mortar and pestle, and homogenate was centrifuged at $15000 \mathrm{Xg}$ at $4^{\circ} \mathrm{C}$ for $30 \mathrm{~min}$ and aliquots were used as the source of enzyme.

\section{Isolation and activity assay of peroxidase (EC 1.11.1.7) and PPO (EC 1.14.18.1)}

Peroxidase activity was determined according to the procedure reported earlier by Kar and Mishra (1976) with the following modifications. Assay mixture for the peroxidase comprised: $2 \mathrm{ml} 0.1 \mathrm{M}$ of phosphate buffer, $\mathrm{pH} 7.0,1 \mathrm{ml} 0.01 \mathrm{M}$ of pyrogallol $\left(\mathrm{C}_{6} \mathrm{H}_{6} \mathrm{O}_{3}\right), 1 \mathrm{ml}$ of $0.005 \mathrm{M}$ hydrogen peroxide $\left(\mathrm{H}_{2} \mathrm{O}_{2}\right)$, and $1 \mathrm{ml}$ of the 2 times diluted enzyme extract. The reference cuvette contained equal volume of the inactivated enzyme (by boiling) and pyrogallol. This was incubated for $5 \mathrm{~min}$. at $25^{\circ} \mathrm{C}$ after which the reaction was stopped by adding $0.5 \mathrm{ml}$ of $5 \%(\mathrm{v} / \mathrm{V})$ $\mathrm{H}_{2} \mathrm{SO}_{4}$. The amount of purpurogallin formed was determined by measuring the absorbance at $420 \mathrm{~nm}$. One unit of peroxidase activity is defined as that amount of the enzyme which cause change of 0.01 absorbance unit per minute under assay condition and was expressed as $\mathrm{U}$ per gram fresh weight $\left(\mathrm{U} \mathrm{gfw}^{-1}\right)$.

Assay mixture of polyphenol oxidase comprised of same ingredients and protocol as in case of peroxidase except $\mathrm{H}_{2} \mathrm{O}_{2}$. One unit of peroxidase activity is defined as that amount of the enzyme which cause change 0.01 absorbance unit per minute under assay condition and was expressed as $\mathrm{U}$ per gram fresh weight (U $\left.\mathrm{gfw}^{-1}\right)$.

\section{Isolation and activity assay of catalase (EC 1.11.1.6)}

The activity of catalase was assayed after the method of Braber (1980) with the following modification. Five $\mathrm{ml}$ of the assay mixture comprised: $300 \mu$ moles of phoshphate buffer, $\mathrm{pH} 6.8100 \mu$ moles of $\mathrm{H}_{2} \mathrm{O}_{2}$, and $1 \mathrm{ml}$ of twice diluted enzyme extracted. After incubation at $25^{\circ} \mathrm{C}$ for $1 \mathrm{~min}$, the reaction was stopped by adding $10 \mathrm{ml}$ of $2 \%(\mathrm{v} / \mathrm{V}) \mathrm{H}_{2} \mathrm{SO}_{4}$ and the residual $\mathrm{H}_{2} \mathrm{O}_{2}$ was titrated against $0.01 \mathrm{~N}$ $\mathrm{KMnO}_{4}$ until a faint purple colour persisted for at least $15 \mathrm{sec}$. A control was run at the same time in which the enzyme activity is defined as that same time in which the enzyme activity was stopped at "zero" time. Catalase activity was expressed as $\mu$ mole of $\mathrm{H}_{2} \mathrm{O}_{2}$ used per minute under the assay condition described, considering the concentration of $\mathrm{H}_{2} \mathrm{O}_{2}$ using the extinction coefficient $0.036 / \mu \mathrm{mol} / \mathrm{ml}$.

Isolation and activity assay of phenylalanine ammonia lyase (EC 4.3.1.5)

Tissues were homogenized in $0.1 \mathrm{M}$ Borate buffer $(\mathrm{pH} 8.8)$ at $4^{\circ} \mathrm{C}$. Homogenate was centrifuged at $4^{\circ} \mathrm{C}$ and $38000 \mathrm{X} \mathrm{g}$ and the supernatant used as enzyme source. The activity of L-phenylalanine ammonia-lyase was determined by the method of Zucker (1965) with certain modifications. Assay mixture consisted of $1.5 \mathrm{ml}$ Borate buffer, $1.0 \mathrm{ml} \mathrm{H}_{2} \mathrm{O}, 1.0 \mathrm{ml}$ phenylalanine solution $(10 \mu \mathrm{M})$ and 0.5 $\mathrm{ml}$ enzyme extract. After incubation of this assay mixture for $2 \mathrm{hrs}$ at $38^{\circ} \mathrm{C}$ water bath, the change of absorbance at $290 \mathrm{~nm}$ compared to a reference sample without added substrate was measured with a spectrophotometer. PAL activity was expressed as $\Delta \mathrm{A}_{290 \mathrm{~nm}} \mathrm{ml}^{-1} \mathrm{~h}^{-1}$.

\section{Isolation and activity assay of chitinase (EC 3.2.1.14)}

Defatted and depigmented tissue powder was stirred with extraction buffer (1:6 w/ $\mathrm{V}$ in $0.1 \mathrm{M}$ phosphate buffer, $\mathrm{pH} 6.9$ containing $0.05 \mathrm{M} \mathrm{NaCl}$ ) at $4^{\circ} \mathrm{C}$ for 12 hrs. The mixture was centrifuged at $10,000 \mathrm{Xg}$ for $20 \mathrm{~min}$ and the proteins form the supernatants were precipitated by adding ammonium sulphate $\left[\left(\mathrm{NH}_{4}\right)_{2} \mathrm{SO}_{4}\right]$ to 90\% saturation (60 g ammonium sulfate per $100 \mathrm{ml}$ extract). The precipitated protein were collected by centrifugation, resuspended and dialyzed against the extraction buffer (Giri et al., 1998).

Chitinase activity was determined as described by Chen $\boldsymbol{e t}$ al. (1982) and Tsukomoto et al. (1984). The reaction mixture contained $1.0 \mathrm{ml}$ of colloidal chitin solution $(7 \mathrm{mg}), 1.0 \mathrm{ml}$ of sodium acetate buffer $(50 \mathrm{mM}, \mathrm{pH} 5.2)$ and 1.0 $\mathrm{ml}$ of suitably diluted enzyme. After incubation at $50^{\circ} \mathrm{C}$ for $1 \mathrm{hr}$, the released reducing sugar was measured as $\mathrm{N}$-acetyl glucosamine (NAG) equivalents by the method of Reissig $\boldsymbol{e t}$ al. (1955). One unit (U) of chitinase activity was defined as the amount of enzyme that produced $1 \mathrm{mg}$ of NAG per hour, under the given assay conditions and expressed as $\mathrm{U}$ per gram fresh weight $\left(\mathrm{U} \mathrm{gfw}^{-1}\right)$.

\section{Isolation and activity assay of glucanase (EC 3.2.1.39)}

$\beta$-1,3-glucanase activity was estimated using the procedure of Koga et al. (1988). The assay mixture contained $1.0 \mathrm{ml}$ of suitably diluted enzyme and $1.0 \mathrm{ml}$ of $1 \%$ laminarin solution in sodium acetate buffer $(50 \mathrm{mM}, \mathrm{pH}$ 5.2).The mixture was incubated at $40^{\circ} \mathrm{C}$ for $30 \mathrm{~min}$ and the released reducing sugar was measured as glucose equivalents (Somogyi, 1952). One unit (U) of $\beta$-1,3-glucanase activity was defined as the amount of enzyme that produced $1 \mathrm{mM}$ of glucose $\left(\mathrm{C}_{6} \mathrm{H}_{12} \mathrm{O}_{6}\right)$ per hour, under the given assay conditions.

\section{RESULTS AND DISCUSSION}

\section{Spatial and temporal activity of peroxidase}

Peroxidase activity increased in all the tissues of all the varieties from pre initiation (S1) to disease initiation stage (S2) and declined thereafter at $\mathrm{S} 3$ i.e. severe diseased stage (Figure 1). This pattern was prominent in case of all challenged as well as un-inoculated plants. In case of S2 stage, irrespective of challenged or un-inoculated plants, there was a significant increase in activity of peroxidase in all the tissues over S1 stage. Conspicuous changes occurred at the rate of increase in activity of the enzyme between resistant and susceptible cultivars upon inoculation with respect to their corresponding control at this stage. The peroxidase activity increased 3.4 fold in root of resistant variety WR 315 in contrast to its control. However, roots of challenged susceptible variety recorded 2.0 fold increase in enzyme activity compared to respective control. Similarly, the rate of increase in the resistant varieties was up to 3.4 fold, whereas, in susceptible variety it was up to 1.5 fold in stem tissue of $F o c$ treated samples. In case of leaves, the increase in activity of this enzyme was recorded as up to $12 \%$ in the resistant varieties of chickpea upon inoculation. Whereas, the activity of peroxidase increased by $3.46 \%$ in leaf tissue of susceptible cultivar compared to control after 15 DAS. Irrespective of inoculated or un-inoculated plants, there was a significant decrease in enzyme activity was observed at $\mathrm{S} 3$ but comparative level of induction of peroxidase was higher in resistant cultivars.

\section{Spatial and temporal activity of polyphenol oxidase}

At S1 stage, under control condition, susceptible chickpea cultivar JG 62 root tissue had the maximum PPO activity $\left(47.32 \mathrm{U} \mathrm{gfw}^{-1}\right)$, whereas resistant variety WR 315 exhibited the minimum (44.34 $\mathrm{U} \mathrm{gfw}^{-1}$ ) activity (Figure 2). Resistant varieties showed induction of PPO activity in roots, whereas the activity in susceptible varieties remained almost unchanged upon inoculation with Foc, Almost all the varieties showed induction at a lower rate at S1 stage in the stem and leaf tissues. At disease initiation stage (S2), increasing rate of induction was attained by resistant cultivars and the induction continued up to severe disease stage (Figure 2). Conversely, induction in susceptible varieties increased at S2 stage compared with those in un-inoculated plants. Foc inoculation elicited considerably higher increase in the rate of enzyme activity in the resistant cultivars of chickpea especially at stem tissue. In the stem tissue of chickpea, the PPO activity in resistant varieties increased by 16.2 and $30 \%$ with respect to control. In susceptible cultivars BG 256 and JG 62 activity increased by $14.6 \%$ and $21.6 \%$, respectively, compared to the controls. Upon pathogen infection, the rate of enzyme activity increased by $23 \%, 8.8 \%, 2.2 \%$ and $2.5 \%$, respectively, in root tissues of all the varieties of chickpea at S2 stage. Induction of the PPO activity continued up to $\mathrm{S} 3$ in resistant cultivars and the enzyme accumulated at a 
significant higher rate in comparison to un-inoculated plants. During progression from S2 to S3 stage, the level of the enzyme diminished and even fell below the control in susceptible varieties.

\section{Spatial and temporal activity of catalase}

Highest activity of catalase $\left(180 \mu \mathrm{mol} \mathrm{H}_{2} \mathrm{O}_{2}\right.$ used $\left.\min ^{-1} \mathrm{gfw}^{-1}\right)$ in roots was

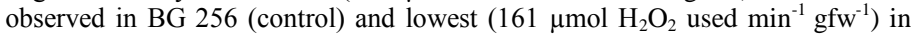
ICC 4958 (un-inoculated control) at $\mathrm{S} 1$ stage. At this stage, in stem tissue, highest activity of catalase $\left(198 \mu \mathrm{mol} \mathrm{H}_{2} \mathrm{O}_{2}\right.$ used $\min ^{-1}$ gfw-1) was observed in ICC 4958 (control) and lowest (167) in JG 62 (control) (Figure 3). Catalase activity in susceptible cultivar of chickpea, BG 256 increased by $3.70 \%$ in root at S2 stage with respect to its control, whereas, in another susceptible cultivar, JG 62 , this change was non-significant. Resistant cultivar WR 315 showed increased activity by $14.90 \%$ in root tissue. In stem tissues of susceptible variety, BG 256 , the activity increased by $7.90 \%$. The major changes were observed in leaf tissues where increase in activity of catalase in resistant cultivar WR 315 and ICC 4958 were 1.4 and 1.5 times, respectively. Increase in activity in cv. JG 62 was 1.2 times and changes in another susceptible variety, BG 256 were non-significant in leaf tissue at S2 stage upon inoculation with Foc over their corresponding controls. Unlike peroxidase and polyphenol oxidase, induction of catalase was mainly in the leaf tissues and continued up to S3 stage. Levels of catalase activity in leaves of challenged plants were about 1.36 and 1.19 times in the resistant cultivars and 1.3 in the susceptible variety JG 62 compared to respective controls (Figure 3).

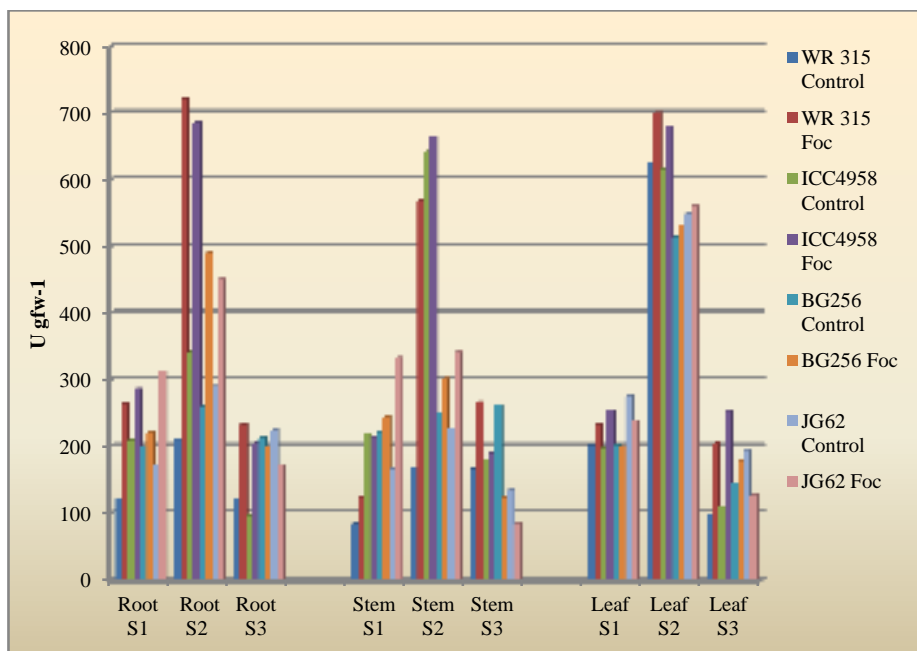

Figure 1 Peroxidase activity $\left(\mathrm{U} \mathrm{gfw}^{-1}\right)$ in different tissues of chickpea cultivars differing in susceptibility to Fusarium wilt

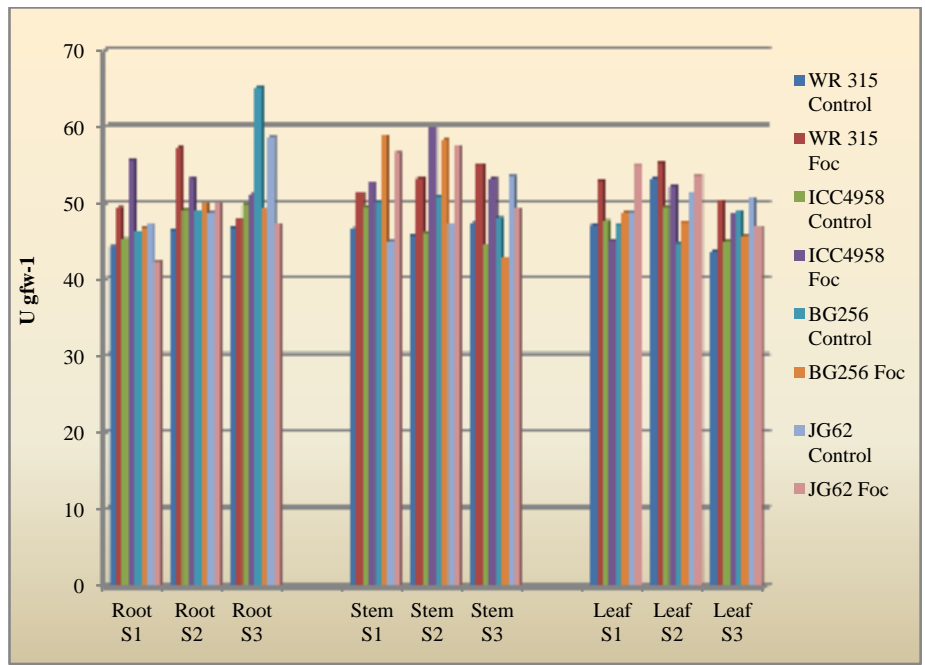

Figure 2 Polyphenol oxidase activity in different tissues of chickpea cultivars differing in susceptibility to Fusarium wilt

\section{Spatial and temporal activity of phenylalanine ammonia lyase}

There was significant increase in PAL activity from S1 to S3 stage (Figure 4) irrespective of whether the plants were inoculated or un-inoculated type. The activity either slightly decreased or remained unchanged at S3 stage. At S1 stage, highest PAL activity was observed in susceptible chickpea cv. JG 62 under uninoculated condition. At S2 stage, resistant cultivars showed up to $28 \%$ increase in activity in roots (Figure 4). As compared with the un-inoculated controls, Fusarium inoculation elicited a sharp increase in the PAL activity at this stage in the leaf and stem tissues. In stem tissues, there were 36.50 and $26 \%$ increase in PAL activity in resistant varieties and 12.80 and $7.00 \%$, respectively, in susceptible varieties with respect to their controls. Similarly in the leaf tissues, PAL activity increased up to $41 \%$ in the resistant varieties but remained unchanged in the susceptible varieties. At S3 stage, highest activity was attained by stem and leaf tissue of resistant cultivars upon infection with respect to its control.

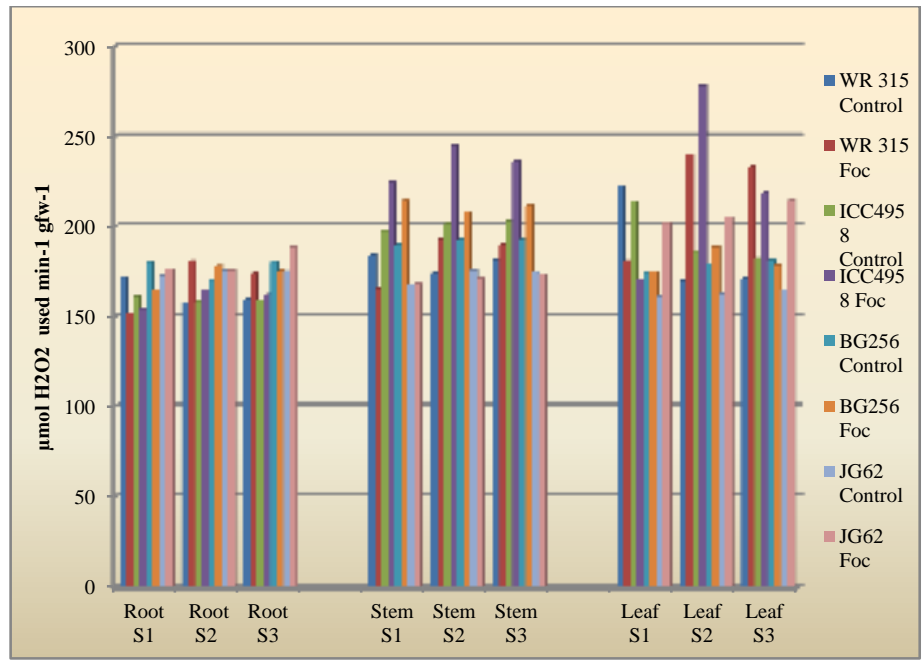

Figure 3 Catalase activity in different tissues of chickpea cultivars differing in susceptibility to Fusarium wilt

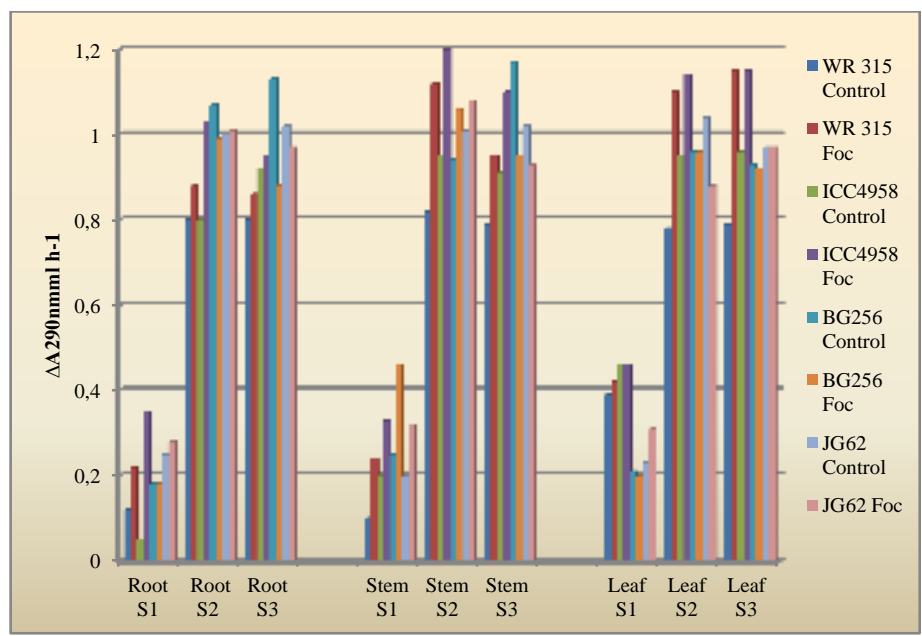

Figure 4 PAL activity in different tissues of chickpea cultivars differing in susceptibility to Fusarium wilt

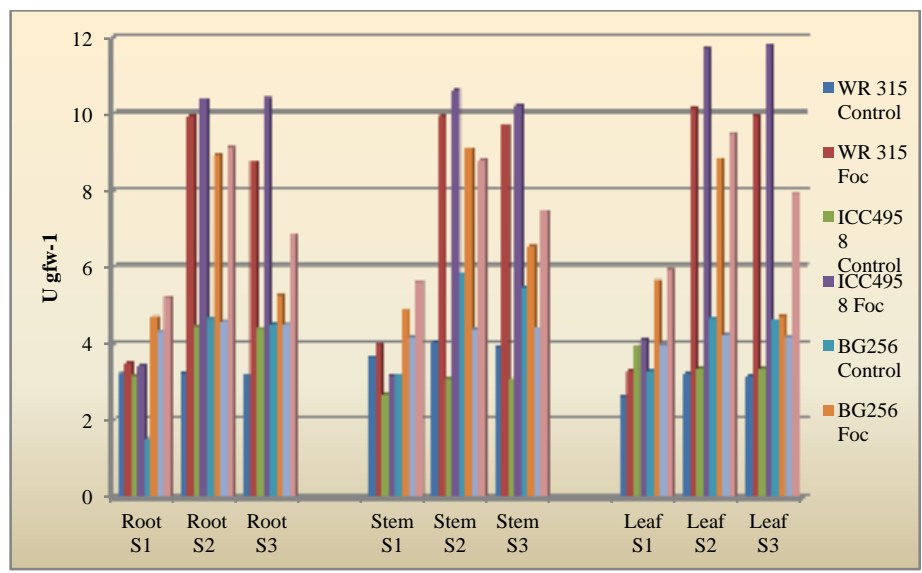

Figure 5 Chitinase activity $\left(\mathrm{U} \mathrm{gfw}^{-1}\right)$ in different tissues of chickpea cultivars differing in susceptibility to Fusarium wilt 


\section{Spatial and temporal activity of chitinase}

Induction of chitinase in chickpea was significantly high in leaves. Like peroxidase and PPO, chitinase activity showed a marked increase in different tissues upon inoculation of the plants with Fusarium. In general the maximum enzymatic activity was observed in resistant cultivars at S2 stage. The enzyme activity increased progressively from $\mathrm{S} 1$ to $\mathrm{S} 2$ stage and thereafter showed decrease with progression of the disease and was very low at S3 stage (Figure 5). On the contrary, these changes were much less conspicuous in case of uninoculated plants, where the increase or decrease was only marginal.

At S1 stage, maximum constitutive level of chitinase activity was observed in leaf, stem and root tissue of susceptible cv. JG 62. The enzyme activity in these tissues was 4.34, 4.17 and $3.99 \mathrm{U} \mathrm{gfw}^{-1}$, respectively (Figure 5). Maximum induction of chitinase activity was observed at S2 stage in the root tissue. In resistant cultivar WR 315 this increase was 3.08 fold and in cv. ICC 4958 increase was 2.3 fold. This increase in activity was lower in susceptible cultivars (1.9 fold only). The enzyme activity significantly increased in comparison to control in the stem tissue of resistant cultivars. More than three-fold increase in enzyme activity was observed in resistant plants compared to respective controls but in susceptible cultivars this increase was only 1.18 and 2.24 fold. At S3, in both control and inoculated plants the increase in activity was not very prominent but resistant cultivars showed higher activity of chitinase than susceptible cultivars.

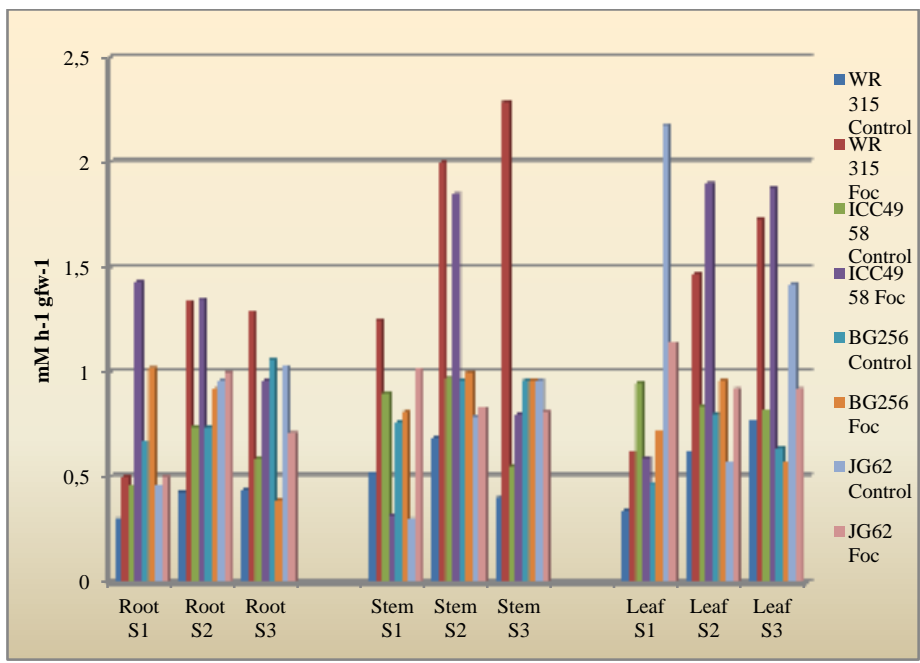

Figure 6 Glucanase activity in different tissues of chickpea cultivars differing in susceptibility to Fusarium wilt

\section{Spatial and temporal activity of $\beta$-1,3-glucanase}

Glucanase activity was high in stem and leaf tissues. Inoculation of the plants with Fusarium recorded a marked increase in glucanase activity in different tissues. In general the maximum enzymatic activity was observed in resistan cultivars at S2 stage and the same was more or less maintained up to S3 stage. This is in contrast to the activity pattern of other enzymes whose levels showed significant decrease at S3 stage. Both control and challenged plants had higher level of activity at later stages of disease development, but the proportionate increase was much higher in resistant cultivars (Figure 6).

In case of chickpea, at $\mathrm{S} 1$ stage maximum $\left(0.67 \mathrm{mM}\right.$ glucose $\left.\mathrm{h}^{-1} \mathrm{gfw}^{-1}\right)$ constitutive level of glucanase activity was observed BG 256 roots. Minimum activity was found in WR $315\left(0.30 \mathrm{mM}\right.$ glucose $\left.\mathrm{h}^{-1} \mathrm{gfw}^{-1}\right)$ (Figure 6). At disease initiation stage (S2) maximum induction of enzymatic activity was in resistant chickpea cultivar WR 315, where this increase was three fold in root and stem compared to control plants of same stage. Whereas, under similar condition, in wilt susceptible chickpea cultivars, the enzymatic activity increase was only 1 to 1.5 fold.

\section{DISCUSSION}

Induction of plant defence against pathogen attack is regulated by a complex network of different signals. In the present study, pathogen-host interaction enhanced defence responses in resistant cultivars of chickpea. Spatial and temporal changes in various enzymes investigated in Fusarium infected and uninoculated plants showed that induction of plants' own defence system started only after the infection by respective pathogen, and subsequently resulted in hypersensitive reaction conferring resistance. Chickpea plants exposed to Foc showed enhanced synthesis of pathogenesis related proteins, activities of PAL and other antioxidant enzymes relative to their controls.
Spatial and temporal activity of anti-oxidant enzymes (PO, PPO and catalase)

Peroxidases are one of the elements of the defence system that are stimulated in plants in response to pathogen infection like Fusarium oxysporum (Morkunas and Gmerek, 2007). The present results indicate that PO, PPO and catalase activities increased in chickpea tissues after inoculation with Foc. In comparison to susceptible cultivars, activities were higher in the resistant cultivars at disease initiation stage. The results are in conformity with Rathi et al. (1986) who also recorded higher PO activity in leaves of wilt resistant variety of pigeon pea. Similarly, Xue et al. (1998) reported that after treatment with bi nucleate Rhizoctonia species, total peroxidase increased two fold in bean tissues of diseased plants compared with control.

Peroxidase activity also showed marked increase even in stems and leaves (other than the site of infection) of chickpea cultivars. This spatial regulation of enzyme activity in distant tissues has been reported by other workers as well in the tissues of plants attacked by necrotizing pathogens including Rhizoctonia and Fusarium species (Anuratha et al., 1996; Mauch et al., 1988). Pathogenic attack on plants appears to cause alterations in protein (enzyme) synthesis in the host leading to the development of local resistance or immune layer around infection sites which depends on the speed and extent synthesis of pathogenesis-related proteins and the accumulation of phytoalexins. Inoculation with inducers resulted in accumulation and shift of peroxidase activities in plant roots along with other defence enzymes. Peroxidase action could still happen in an indirect way through the activity of sub products, which posses an antimicrobial activity or by inducing the formation of structural barriers. In the present study, one susceptible chickpea cultivar, BG 256 showed $20 \%$ increase in peroxidase activity in stem tissue at S2 stage, where as the resistant cv. ICC 4958 showed only $3.4 \%$ increase under similar condition. In susceptible plants, high level of enzyme activities are maintained as the pathogen remains active in the plant tissue (Beckman and Roberts, 1995). Comparative lower rate of induction in resistant cultivars may be associated with the reduction in the pathogen invasion as a result of the defence reaction.

Higher activity of PPO was observed in resistant chickpea cultivars than susceptible cultivars, upon inoculation by Fusarium and the difference was prominent in root and stem than in the leaf tissues. Retig (1974) proposed that host-pathogen interaction induces the peroxidase and phenol oxidases that increase the production of phenols oxidized at the cell walls and through this activity the cell efforts for the establishment of a physicochemical barrier, able to isolate the infected areas. In current observations on chickpea, a significant increase in activity in resistant cultivars WR 315 and ICC 4958 by 23 and $8 \%$ is noticed over susceptible varieties where increase was 2.2\% (BG 256) and 2.5\% (JG 62) in root tissue. In stem, again the increase was very substantial and proves the resistant nature of WR 315 and ICC 4958. Induction of PPO increased by up to $52 \%$ over the susceptible varieties. Similar results were observed by Raju $\boldsymbol{e t}$ al. (2008) in chickpea showing higher PPO activities in resistant cultivar ICCV 10 upon infection. They induced PPO-2 isoform in roots and shoots treated with salicylic acid, spermidine and the pathogen which have also been implicated in defence responses against the pathogen invasion. However, no induction of PPO was observed in susceptible cultivars. In the present study, induction was not noticed in susceptible cultivars in root, stem and leaves at severe disease stage (S3) upon inoculation. Systemic induction of PPO expression in response to wounding and pathogens might provide an additional line of defence to protect plants against further attack by pathogen and insects (Thipyapong et al., 1995; Stout et al., 1999). The PPO over-expressing transgenic tomato plants exhibited high resistance to Pseudomonas syringae, the causative agent of speck disease compared to control plants ( $\mathbf{L i}$ and Stiffens, 2002). Localized inoculation of tomato leaflets with $P$. syringae induces a significant increase in PPO activity and leads to systemic resistance to the subsequent infection by $P$. syringae (Stout et al., 1999). These results and Thipyapong and Stiffens (1997) indicate that the oxidative enzyme PPO converts the phenolic compounds of plants into polyphenols and quinines which help in limiting disease development. Significant changes in induction of enzyme from S1 through S3 level in all varieties establishes the fact that enzymes are induced at high amount only after pathogen infection and disease initiation and the accumulation pattern of peroxidase and polyphenol oxidase is correlated (activity of peroxidase being higher than PPO). PPO induction was more in stem tissues, whereas peroxidase induction was higher in leaf tissue and conforms to spatial distribution of PO and PPO (Raju et al., 2008). Catalase activities were similar to PO and PPO and its induction started at S2 (15 DAS) in un-inoculated control plants. Increase in induction was significant in leaf tissues of both the plants upon infection as compared to controls and it continued up to S3 stage. This fact resembles Subramanian et al. (2006) where the level of $\mathrm{H}_{2} \mathrm{O}_{2}$ and other enzyme activities increased to the level of tolerance or susceptibility to Fusarium wilt disease. El-Khallal (2007) also reported similar results in Fusarium infected tomato plants. Susceptible chickpea cv. BG 256 showed 30\% increase in enzymatic activities over the resistan varieties at S3 stage in leaves after infection which might be due to the invasion of the pathogen and subsequent host cell wall degradation with the release of particular enzyme at the vicinity of the infection site. Cells in the immediate vicinity of infection site die making it impossible for the pathogen to spread 
through the plant. Such hypersensitive responses of the plants result in enhanced resistance of the uninfected plants known as induced or acquired resistance (Van de Rhee et al., 1994).

\section{Spatial and temporal activity of phenyl alanine ammonia lyase}

In our studies PAL activity increased in response to pathogen treatments as observed by Song et al. (1993) and Arfaoui et al. (2007). In another study, chickpea seedlings exposed to cell wall proteins of $F$. oxysporum f. sp. ciceri, showed enhanced synthesis of phenols, pathogenesis-related proteins and activities of PAL and peroxidase relative to water treated controls (Saikia $\boldsymbol{e t}$ al. 2005). Stadnik and Buchenauer (2000) also reported the enhancement of PAL activity and accumulation of cell wall-bound phenolic compounds in wheat plants treated with BTH, a novel systemic acquired resistance (SAR) inducer in response to powdery mildew infection. The present results show a rapid increase of PAL activity in pathogen treated chickpea seedlings and except for the control treatment, there were differences in PAL activity among the different cultivars. Increased activity of PAL in resistant cultivar might have prevented the fungal invasion and therefore maintained at higher levels during the experimental period. Increased accumulation of PAL with pathogen re-establishes the notion that PAL is synthesized more rapidly in resistant cultivars than that in susceptible cultivars in response to invasion of pathogen. The phenolic compounds may contribute to enhance the mechanical strength of host cell wall and may also inhibit the fungal growth. Altering the level of phenolic compounds in plants has been demonstrated to change disease susceptibility (Yao et al., 1995) and higher accumulation of phenolics has been reported in the resistant cultivar than the susceptible cultivars after Fusarium infection (Datta and Lal, 2012).

\section{Spatial and temporal activity of Chitinase and $\beta$-1,3-glucanase}

Inhibition of growth of several fungi requires the presence of chitinases and $\beta$ 1,3-glucanase activities for depolymerisation of cell wall polymers (Saikia $\boldsymbol{e t}$ al. 2005). Induction of chitinases and $\beta$-1,3-glucanases in plants treated with stres agents or infected with various fungi is common (Krebs and Grumet, 1993) Ferraris et al. (1987) found that infection with $F$. oxysporum f. sp. lycopersici caused several fold increases in chitinases, $\beta$-1,3-glucanases, glucosidases and $\mathrm{N}$ acetyl-glucosaminidases activities in susceptible and resistant tomato cultivars from 5 to 90 days after inoculation. The present study in chickpea proved that chitinase activity was increasing 3.08 and 2.33 fold in root tissue, 2.45 fold and 3.43 fold in stem tissue, 3.15 fold and 3.5 fold in leaf tissues of chickpea resistant cultivars whereas in susceptible cultivars activity increased up to 2 fold upon infection. Similarly, in case of $\beta$-1,3-glucanases, the activity increased by $2-3$ fold in resistant cultivars and 1-1.5 fold in susceptible varieties of chickpea. Giri et al. (1998) analysed the levels of these two enzymes in resistant and susceptible cultivars of chickpea during Fusarium wilt development and found induction of chitinase activity in both resistant and susceptible cultivars; however enzyme activity in susceptible cultivar JG 62 was much lower than that of resistant cultivar. Further, the activities of these two enzymes increased several fold from S1 to S2 stage both in control and treated condition and declined thereafter and the induction was very low in the control condition. This fact is also supported by work of Saikia et al. (2005) where purified proteins also exhibited antifungal activity by inhibiting the radial growth of different fungal species, e.g. $F$. oxysporum. f. sp. ciceri, F. udum and M. Phaseolina. In general, chitinase exhibited more antifungal activity in comparison to $\beta$-1,3-glucanase in vitro. Rakshit et al. (2000) reported that increase in $\beta$-1,3-glucanase activity was most conspicuous and drastic in resistant genotypes as compared to the susceptible ones in pea after infection with powdery mildew. Xue et al. (1998) observed relatively higher activity of chitinase in the cotyledons of bean plants than hypocotyls and a significant increase of peroxidase, $\beta$-1,3-glucanases and chitinase in all cellular fractions of diseased plants as compared to control, and $\beta$ 1,3-glucanases activity recorded increase up to 18 fold in induced bean hypocotyls tissues. Similar increases, but not as pronounced have been reported from ISR studies using incompatibility interactions between soybean and Phytophthora megasperma f. sp. glyciensi (Yi and Hwang, 1996) and between resistant bean cultivars and $C$. lindemuthianum (Daugrois et al., 1990). In the present study, chitinase significantly accumulated in different tissues after the onset of diseases and the same has been reported in other systems of hostmicrobe interactions where different types of chitinases are expressed depending on the type of plant tissue and developmental stages (Igratius et al., 1994). Seed associated chitinases of barley are different from those that found in leaves infected with powdery mildew (Igratius $\boldsymbol{e t}$ al., 1994) while Anuratha $\boldsymbol{e t}$ al. (1996) isolated an infection related chitinase transcript that was only induced upon infection of rice with the sheath blight pathogen $R$. solani.

The defence responses were induced in both pre-induced and non-induced plants infected by pathogens and the suppression of Fusarium wilt possibly involved an inhibitory effect on the pathogen of pre-induced plant defences, as well as induced defence. Chickpea resistant cv. ICC 4958 did not show significant increase in activity of $\beta$-1,3-glucanase in root tissue at S2 stage as compared to susceptible cultivars. Activity increased in shoot and cotyledon of both resistant and susceptible cultivars at 10 and 18 days after germination. The increase in activities in susceptible hosts may have been a result of failure of containment of the pathogen and the colonization of ever increasing amounts in the vascular tissue. Benhamou et al. (1990) observed faster accumulation of these enzymes in incompatible interactions of tomato and Fusarium oxysporum $\mathrm{f}$. sp. lycopersici or Fusarium radicis-lycoperscici than in a compatible interaction. Beckman and Roberts (1995) in their model for host-pathogen interaction, suggested callose deposition and lignifications as one of the plants responses against wilt disease and rate of these processes determining the degree of reduction of pathogen invasion. The observed decrease in $\beta-1,3$-glucanse activity in resistant cultivars in root and stem tissues may be associated with the higher rate of callose deposition. When expression of $\beta$-1,3-glucanase is specifically blocked by the antisense mRNA technique, callose deposits are protected from degradation, resulting in resistance to viral infection in tobacco (Beffa et al., 1996). In the present study, levels of chitinase and $\beta-1,3$-glucanases are reduced as the infection is confined at S3 stage. This decrease may be associated with the reduction in the pathogen invasion as a result of defence reaction. In summary, this study indicates that Fusarium are inducers of these enzymes at both the local and systemic level in tissues of chickpea.

Antibiotic phenols have been found in all cultivars of chickpea investigated in the present study (Datta and Lal, 2012). Some occurred constitutively and were thought to function as pre-formed inhibitors. Others are formed in response to the ingress of pathogen and their appearances are considered as part of an active defence response. The de novo synthesis and differential accumulation of antifungal phytoalexins in incompatible and compatible plant pathogen interactions play crucial roles in the specificity of host resistance. Priming resistance by inducing phytoalexin biosynthesis genes could be an efficient and inexpensive way of achieving the control of Fusarium wilt in chickpea. The present results show that the infection by Fusarium can effectively result in the accumulation of PAL. Several hypotheses can be formulated to explain the level of phenolics and PAL in the plants following Foc infection like (i) de novo mRNA synthesis or accumulation of defence related genes such as PAL, and (ii) increase in accumulation of phenolics may occur, upon challenge by Fusarium, and release of phytoalexins from their preformed conjugated forms. Furthermore, these two mechanisms generating phytoalexins can act synergistically. Datta and Lal (2012) also confirmed that the accumulation of phenolic compounds in resistant cultivars was induced only in the plants inoculated with Foc although both susceptible and resistant cultivars were responsive to the Fusarium inoculation in inducing the defence related genes. Induced resistance is multicomponent and it is necessary to investigate further other mechanisms involved, either alone or collectively and focus on isolation and transfer of disease resistance genes as part of an integrated wilt management strategy.

\section{CONCLUSION}

The present study on temporal and spatial variation in antioxidant enzymes and PR proteins reveals that the expression pattern of defense related proteins could be used as markers for the establishment of resistance. The host is protected against pathogen both by passive (physical barriers) and active (phytoalexins) mechanism using defense enzymes. The isolation of pathogen-induced defense enzyme genes bears scope for their cloning, manipulation of expression and development of transgenic crop plants resistant to various pathogens.

\section{REFERENCES}

Anuratha, C.S., Zen, K.C., Cole, K.C., Mew, T., \& Muthukrishnan, S. (1996) Induction of chitinases and $\beta$-1, 3-glucanases in Rhizoctonia solani-infected rice plants: Isolation of an infection-related chitinases DNA clone. Physiol Plant, 97, 39-46. https://doi.org/10.1111/j.1399-3054.1996.tb00476.x

Arfaoui, A.E., Hadrami, Y., Mabrouk, B., Sifi, A., Boudabus, I., Hadrami, E.I., Daayf, F., \& Cherif, M. (2007). A treatment of chickpea with Rhizobium isolates enhances the expression of phenylpropanoid defense-related genes in response to infection by Fusarium oxysporum f. sp. ciceris. Plant Physiol Biochem, 45, 470479. https://doi.org/10.1016/j.plaphy.2007.04.004

Beckman, C.H., \& Roberts, E.M. (1995). On the nature and genetic basis for resistance and tolerance to fungal wilt diseases of plants. Adv Bot Res, 21, 36-72 https://doi.org/10.1016/S0065-2296(08)60008-7

Beffa, R.S., Hofer, R.M., Thomas, M., \& Meins, F. Jr, (1996). Decreased susceptibility to viral disease of $\beta$-1, 3-glucanase deficient plants generated by antisense transformation. The Plant Cell, 8, 1001-1011. https://doi.org/10.1105/tpc.8.6.1001

Benhamou, N., Joosten, M.H.A.J., \& de Wit, P.J.G. (1990). Subcellular localization of chitinase and of its potential substrate in tomato root tissues infected by Fusarium oxysporum f. sp. radices-lycopersici. Plant Physiol, 92, 1108-1120. https://doi.org/10.1104/pp.92.4.1108

Braber, J.M. (1980). Catalase and peroxidase in primary bean leaves during development and senescence. Z Pflanzenphysiol, 97, 135-144. https://doi.org/10.1016/S0044-328X(80)80027-4

Broetto, F., Marchese, J.A., Leonardo, M., \& Regina, M. (2005). Fungal elicitormediated changes in polyamine content, phenylalanine ammonia-lyase and peroxidase activities in bean cell culture. Gen Appl Plant Physiol, 31, 235-246. 
http://www.bio21.bas.bg/ippg/bg/wp-content/uploads/2011/06/05_3-4_235-246$\underline{\text { s.pdf }}$

Chen, A., Mayor, R., \& Deloach, J. (1982). Purification and characterisation of chitinase from a stable fly Stomoxys calcitrans. Arch Biochem Biophys, 216, 314 321. https://doi.org/10.1016/0003-9861(82)90216-8

Datta, J., \& Lal, N. (2012). Temporal and spatial changes in phenolic compounds in response to Fusarium wilt in chickpea and pigeonpea. Cell Mol Biol, 58, 96102. https://www.cellmolbiol.org/index.php/CMB/article/view/583

Daugrois, J.H., Lafitte, C., Barthe, J.P., \& Touze, A. (1990). Induction of 1,3- $\beta$ glucanase and chitinase activity in compatible and incompatible interactions between Colletotrichum lindemuthianum and bean cultivars. J Phytopathol, 130, 225-231. https://doi.org/10.1111/j.1439-0434.1990.tb01171.x

Dehgahi, R., Subramaniam, R., Zakaria, L., Joniyas, A., Beiki, F., \& Firouzjahi, B. (2015). Review of Research on Fungal Pathogen Attack and Plant Defense Mechanism against Pathogen. Int J Scient Res Agric Sci, 2, 197-208. http://dx.doi.org/10.12983/ijsras-2015-p0197-0208

El-Khalal, S.M. (2007). Induction and modulation of resistance in Tomato plants against Fusarium wilt disease by bioagent fungi (Arbuscular Mycorrhiza) and/o hormonal elicitors (Jasmonic acid and Salicylic acid): 2- Changes in the antioxidant enzymes, phenolic compounds and pathogenesis-related proteins. Aust J Basic \& Appl Sci, 1, 717-732. http://www.ajbasweb.com/old/ajbas/717732.pdf

Ferrais, L., Abbattista Gentile, I., \& Matta, A. (1987). Variations of phenols concentration as a consequence of stresses that induce resistance to Fusarium wilt of tomato. $Z$ Pflanzenk Pflanzens, 94, 624-629. http://www.jstor.org/stable/43385627

Giri, P., Harsulkar, A.M., Patankar, A.G., Gupta, V.S., Sainani, M.N., Deshpande, V.V., \& Ranjekar, P.K. (1998). Association of induction of protease and chitinase in chickpea roots with resistance to Fusarium oxysporum f. sp Ciceri. Plant Pathol, 47, 693-699. https://doi.org/10.1046/j.13653059.1998.00299.x

Igratius, S.M.J., Chopra, R.K., \& Muthukrishnan, S. (1994). Effects of fungal infection and wounding on the expression of chitinases and $\beta-1,3$-glucanases in near-isogenic lines of barley. Physiol Plant, 90, 584-592. https://doi.org/10.1111/j.1399-3054.1994.tb08818.x

Joshi, P.K., Parthasarathy Rao, P., Gowda, C.L.L., Jones, R.B., Silim, S.N., Saxena, K.B., \& Kumar, J (2001). The world chickpea and pigeonpea economies: facts, trends, and outlook. ICRISAT, Patancheru, India, p. 68 http://www.icrisat.org/PDF/Outlook\%20rep-The\%20World\%20Chickpea.pdf Kar, M., \& Mishra, D. (1976). Catalase, Peroxidase and Polyphenoloxidase activities during Rice leaf senescence. Plant Physiol, 57, 315-319. https://doi.org/10.1104/pp.57.2.315

Koga, D., Sueshige, M., Orikono, K., Utsmi, T., Tanaka, S., Yamada, T., \& Ede, A. (1988). Efficiency of chitinolytic enzymes in the formation of Trichoderma matsutake protoplasts. Agr Biol Chem, 52, 2091-2093. https://www.jstage.jst.go.jp/article/bbb1961/52/8/52 8 2091/_pdf

Krebs, S.L., \& Grumet, R. (1993). Affinity purification and characterization of a $\beta-1,3$-glucanase from celery. Plant Sci, 93, 31-39. https://doi.org/10.1016/01689452(93)90032-U

Li, L., Stiffens, \& J.C. (2002). Overexpression of polyphenol oxidase in transgenic tomato plants results in enhanced bacterial disease resistance. Planta, 215, 239-247. https://doi.org/10.1007/s00425-002-0750-4

Markunas, I., \& Gmerek, S. (2007). The possible involvement of perioxidase in defense of yellow lupin embryo axes against Fusarium oxysporum. J Plant Physiol, 164, 497-506. https://doi.org/10.1016/j.jplph.2005.11.005

Mauch, F., Mauch, M.B., \& Boller, T. (1988). Antifungal hydrolyses in pea tissue. I. Purification and Characterization of two Chitinases and two $\beta-1,3$ glucanases differentially regulated during development and in response to fungal infection. Plant Physiol, 87, 325-333. https://doi.org/10.1104/pp.87.2.325

Raju, S., Jayalakshmi, S.K., \& Sreeramulu, K. (2008). Comparative study on the induction of defense related enzymes in two different cultivars of chickpea (Cicer arietinum $\mathrm{L}$.) genotypes by salicylic acid, spermine and Fusarium oxysporum $\mathrm{f}$. sp. ciceris. Aust J Crop Sci, 2, 121-140. http://www.cropj.com/Microsoft\%20Word\%20-\%20Main\%20sreer\%20121140.pdf
Rakshit, S., Mishra, S.K., Dasgupta, S.K., \& Sharma, B. (2000). Dynamics of $\beta$ 1,3 Glucanase Activity in Powdery Mildew Resistant and Susceptible Lines of

Pea (Pisum sativum L). J Plant Biochem Biotechnol, 9, 95-98. https://doi.org/10.1007/BF03263091

Ramachandra, K.K., Vasanthi, N.S., \& Shetty, H.S. (2000). Induction of $\beta-1,3-$ glucanase in seedlings of pearl millet in response to infection by Sclerospora graminicola. Eur J Plant Pathol, 106, 267-274. https://doi.org/10.1023/A:1008771124782

Rathi, Y.P.S., Bhatt, A., \& Singh, U.S. (1986). Biochemical changes in pigeonpea (Cajanus cajan (L.) Millsp.) leaves in relation to resistance against sterility mosaic disease. $J$ Biosci 10, 467-474. https://doi.org/10.1007/BF02900507

Reissig, J.L., Strominger, J.L., \& Leloir, L.F. (1955). A modified colorimetric method for the estimation of $N$-acetylamino sugars. J Biol Chem, 217, 959-966. http://www.jbc.org/content/217/2/959.full.pdf

Saikia, R., Singh, B.P., Kumar, R., \& Arora, D.K. (2005). Detection of pathogenesis-related proteins- chitinase and $\beta-1,3$-glucanase in induced chickpea. $\begin{array}{llll}\text { Curr } & \text { Sci, } & 89, & 659-663 .\end{array}$ http://www.currentscience.ac.in/Downloads/download_pdf.php?titleid=id_089_0 4_0659_0663_0

Somogyi, M. (1952). Notes on sugar determination. J Biol Chem, 195, 19-23. http://www.jbc.org/content/195/1/19.full.pdf

Stadnik, M.J., \& Buchenauer, H. (2000). Inhibition of phenylalanine ammonialyase suppresses the resistance induced by benzothiadazole in wheat Blumeuia graminis f. sp. tritici. Physiol Mol Plant Pathol, 57, 25-34. https://doi.org/10.1006/pmpp.2000.0276

Stout, M.J., Fidantsef, A.L., Duffey, S.S., \& Bostock, R.M. (1999). Signal interactions in pathogen and insect attack: systemic plant-mediated interactions between pathogens and herbivores of the tomato, Lycopersicon esculentum. Physiol Mol Plant Pathol, 54, 115-130. https://doi.org/10.1006/pmpp.1998.0193 Subramanian, S., Moziah, M., Sariah, M., Puad, M.P., \& Xavier, R. (2006). Bioassay method for testing Fusarium wilt disease tolerance in transgenic banana. $\quad S c i \quad$ Hortic, $\quad 108, \quad 378-389$ https://www.deepdyve.com/lp/elsevier/bioassay-method-for-testing-fusariumwilt-disease-tolerance-in-1ft9mIPAZr

Swarupa, V., Ravishankar, K., \& Rekha, A. (2014). Plant defense response against Fusarium oxysporum and strategies to develop tolerant genotypes in banana. Planta, 239, 735-751. https://doi.org/10.1007/s00425-013-2024-8

Tahsili, J., Sharifi, M., Safaie, N., Esmaeilzadeh-Bahabadi, S., \& Behmanesh, M. (2014). Induction of lignans and phenolic compounds in cell culture of Linum album by culture filtrate of Fusarium graminearum. J Plant Interact, 9, 412-417. http://dx.doi.org/10.1080/17429145.2013.846419

Thipyapong, P., Hunt, M.D., \& Steffens, J.C. (1995). Systemic wound induction of potato (Solanum tuberosum) polyphenol oxidase. Phytochemistry, 40, 673676. https://doi.org/10.1016/0031-9422(95)00359-F

Thipyapong, P., \& Stiffens, J.C. (1997). Tomato Polyphenol oxidase differential response of the PPO F promoter to injuries and wound signals. Plant Physiol, 115, 409-418. https://doi.org/10.1104/pp.115.2.409

Tsukomoto, T., Koga, D., Ide, A., Ishibashi, T., Horinomatsoslig, M., Yagishita, K., \& Imoto, T. (1984). Purification and some properties of chitinase from yam Dioscorea opposita Thumb. Agr Biol Chem, 48, 227-232. http://dx.doi.org/10.1080/00021369.1984.10866241

Tullu, A., Muehlbauer, F.J., Siomn, C.J., Mayer, M.S., Kumar, J., Kaiser, W.J., \& Draft, J.M. (1998). Inheritance and linkage of a gene for resistance to race 4 of Fusarium wilt and RAPD markers in chickpea. Euphytica, 102, 227232. https://doi.org/10.1023/A:1003604209476

van de Rhee, M.D., Linthorst, H.J.M., \& Bol, J.F. (1994). Pathogen-induced gene expression. In AS Basra, ed, Stress-Induced Gene Expression in Plants. Hanvood Academic, Chur, Switzerland, pp. 249-284

Xue, L., Charest, L.M., \& Jabaji Hare, S.H. (1998). Systemic Induction of peroxidases, 1,3- $\beta$-glucanases, chitinases, and resistance in bean plants by binucleate Rhizoctonia species. Phytopathology, 88, 359-365. http://dx.doi.org/10.1094/PHYTO.1998.88.4.359

Yao, K., De, L.V., \& Brisson, N. (1995). Creation of a metabolic sink for tryptophan alters the phenylpropanoid pathway and the susceptibility of potato to Phytophthora infestans. The Plant Cell, 7, 1787-1799. https://doi.org/10.1105/tpc.7.11.1787

Yi ,S.Y., \& Hwang, B.K. (1996). Differential induction and accumulation of $\beta-1$, 3 -glucanase and chitinase isoforms in soybean hypocotyls and leaves after compatible and incompatible infection with Phytophthora megasperma f. sp. glycinea. Physiol Mol Plant Pathol, 48, 179-192. https://doi.org/10.1006/pmpp.1996.0016

Zucker, M. (1965). Induction of Phenylalanine ammonia-lyase by light and its relation to chlorogenic acid synthesis in potato tuber tissue. Plant Physiol, 40 779-784. https://doi.org/10.1104/pp.40.5.779 